\title{
Functional remodeling of lysosomes by type I interferon modifies host defense
}

$4 \quad$ Hailong Zhang ${ }^{1,2,3}$, Abdelrahim Zoued ${ }^{1,2,3}, \mathrm{Xu} \mathrm{Liu}^{1,2,3}$, Brandon Sit $^{1,2}$, Matthew K. Waldor ${ }^{1,2,3 *}$

1Division of Infectious Diseases, Brigham and Women's Hospital, Boston, Massachusetts, USA 


\section{SUMMARY}

Organelle remodeling is critical for cellular homeostasis, but host factors that control organelle function during microbial infection remain largely uncharacterized. Here, a genome-scale CRISPR/Cas9 screen in intestinal epithelial cells with the prototypical intracellular bacterial pathogen Salmonella led us to discover that type I interferon (IFN-I) remodels lysosomes. Even in the absence of infection, IFN-I signaling modified the localization, acidification, protease activity and proteomic profile of lysosomes. Proteomic and genetic analyses revealed that multiple IFN-I-stimulated genes including Ifitm3, Slc15a3, and Cnp contribute to lysosome acidification. IFN-I-dependent lysosome acidification stimulated intracellular Salmonella virulence gene expression, leading to rupture of the Salmonella-containing vacuole and host cell death. Moreover, IFN-I signaling promoted in vivo Salmonella pathogenesis in the intestinal epithelium, where Salmonella initiates infection. Our findings explain how an intracellular bacterial pathogen co-opts epithelial IFN-I signaling. We propose that IFN-I control of lysosome function broadly impacts host defense against diverse viral and microbial pathogens.

\section{KEYWORDS}

Type I interferon, Lysosome remodeling, Salmonella pathogenesis, Intestinal epithelium,

1 Mucosal defense 


\section{INTRODUCTION}

34 Microbial pathogens have evolved varied virulence strategies to modulate host cell function

35 (Geoghegan and Holmes, 2018; Ribet and Cossart, 2015). A common mechanism, employed by

36 all viral and some bacterial pathogens, is to enter host cells, where they co-opt cellular

37 functions while simultaneously evading extracellular threats such as innate and adaptive immune mechanisms (Hybiske and Stephens, 2008; Lee et al., 2019). Inside cells, intracellular pathogens interact with and exploit host cell organelles to support their proliferation (Omotade and Roy, 2019). As a result of their intimate relationships with and manipulation of varied host cell functions, intracellular pathogens have proven to be outstanding tools to probe basic eukaryotic cell biology (Welch, 2015).

Compared to knowledge of how microbial pathogens interact with phagocytic cells, less is

44 known about the landscape of pathogen-epithelial cell interactions at barrier sites, where most infections originate (Jo, 2019). The human foodborne pathogen Salmonella enterica serovar

46 Typhimurium (Stm) is a model intracellular bacterium that initially invades and subsequently

47 kills intestinal epithelial cells (IECs) before spreading systemically via circulating phagocytes

48 (Hurley et al., 2014). Stm's entry into and initial trafficking inside IEC is well-characterized, and a hallmark of Stm infection is the formation of the Salmonella-containing vacuole (SCV), a dynamic, lysosome-like compartment that is permissive for Stm replication (Steele-Mortimer, 
54 (IFN-Is), which include IFN $\alpha$ and IFN $\beta$ (Hess et al., 1989). IFN-Is are cytokines that, once

IFN-stimulated genes (ISGs) (Schoggins and Rice, 2011). Due to the large size of the

proteins (Hubel et al., 2019), knowledge of the full spectrum of IFN-I-mediated changes in cellular function is incomplete. Although IFN-Is are known to have critical roles in antiviral pathogen (Kovarik et al., 2016).

Here, we carried out a genome-scale CRISPR/Cas9 screen to identify the host factors that

71 virulence gene expression, and in vivo studies confirmed a role for epithelial IFN-I signaling in

72 promoting systemic Stm infection. IFN-I signaling mediated control of lysosome function likely 
RESULTS

\section{A CRISPR/Cas9 screen identifies IEC factors required for Stm cytotoxicity}

77

78

As large-scale genetic screens to identify epithelial cell factors that mediate interactions with intracellular pathogens are lacking, we performed a multi-round, genome-wide CRISPR/Cas9 loss-of-function screen in the human colonic epithelial cell line HT29-Cas9 (Blondel et al., 2016), to identify IEC genes that confer resistance to Stm cytotoxicity (Figure 1A). HT29 cells are efficiently invaded and subsequently killed by Stm, providing a strong selective force to enrich for guide RNAs targeting host factors that modulate cytotoxicity. The screen identified known pathways that sensitize cells to Stm infection, including those involved in regulation of actin dynamics (Arp2/3 and Rac), which are important in pathogen invasion (Table S1 and Figures 1B, C), (Unsworth et al., 2004; Yeung et al., 2019). Genes linked to pathways not previously directly linked to Stm virulence, including the Fc-gamma receptor-dependent phagocytic and GPI anchor modification pathways were also enriched (Figures 1B, C).

Strikingly, the top 'hits' of the screen were remarkably coherent - the seven most enriched guide RNAs from both libraries screened corresponded to genes in the IFN-I signaling pathway, including the receptor (Ifnarl/Ifnar2), adaptor (Jak1/Tyk2), and transcription factor (Stat1/Stat2/Irf9) components of the system (Figures 1D, E), suggesting that IFN-I signaling is a major driver of Stm-mediated cytotoxicity in IECs. 
Stm induces IFN-I production during infection (Hess et al., 1989), but the function of IFN-I signaling in IECs is unknown. A clonal knockout of Ifnar2, the top enriched hit in both libraries, was constructed in the HT29-Cas9 background (Figure S1A), to validate the screen findings. At both early and late infection time points, Ifnar2 $\mathrm{KO}$ cells were more resistant to Stm-induced cell death than the wild-type (WT) parental line (Figure 2A and S1B, C). Priming cells with IFN $\beta$ (a major IFN-I), conditions that mimic the multiple rounds of the original screen, further sensitized WT but not Ifnar2 KO cells to death (Figure 2A). To complement these findings, we treated WT cells with chemical inhibitors of JAK-STAT signaling, the downstream target of activated IFNAR1/2. Similar to Ifnar2 KO cells, treatment with the JAK inhibitors ruxolitinib and pyridone-6 also diminished Stm-induced death in WT cells, indicating active IFN-I signaling is required for this phenotype (Figure 2B).

prior data that this cytokine enhances necroptosis in Stm-infected macrophages (Robinson et al., 2012). However, it is not clear whether macrophage and epithelial cell responses to Stm infection are similar; furthermore, it is known that Stm-induced cell death in macrophages is invasion-independent (van der Velden et al., 2000). Thus, we next tested whether IFN-I-promoted epithelial cell death depended on SPI-1 or SPI-2, critical Salmonella pathogenicity islands that each encode type 3 secretion systems (T3SS) required for cellular invasion and intracellular survival, respectively (Galan et al., 2014). SPI-1-deficient ( $\Delta p r g H$ ) 
still detectable levels of cytotoxicity that remained sensitive to IFN $\beta$ priming, suggestive of both SPI-2-dependent and independent mechanisms of intracellular Stm-induced cytotoxicity (Figure 2A).

In support of the population-level LDH assays, flow cytometry of HT29 or HeLa cells infected with fluorescent Stm and stained with the cell death probe Annexin-V indicated that IFN-I only influenced cell death in the population of cells that contained intracellular Stm (Figures 2C and S1D-F). In addition, we found that. IFN-I signaling did not impact Stm invasion (Figures 2D and S2A), nor did it influence bacterial association with the early endosomal marker Rab5, late endosomal marker Rab7 or lysosomal marker LAMP1 (Desjardins et al., 1994) (Figures 2E, F and S2B-E). Together, these data suggest that IFN-I-mediated sensitization of epithelial cells to Stm occurs downstream of cell invasion and initial SCV formation.

\section{IFN-I regulates lysosome localization and function}

During our analyses of SCV formation, we unexpectedly observed that IFN-I signaling alters the subcellular localization of lysosomes in epithelial cells, even in the absence of infection. In HeLa cells, lysosomes (identifiable as LAMP1+/Lysotracker+ co-staining organelles) were scattered throughout the cytoplasm under basal conditions. Following IFN $\beta$ stimulation, lysosomes re-localized to the perinuclear region (Figures 3A, B, Video S1, 2); lysosome re-localization was not observed in Ifnar2 $\mathrm{KO}$ HeLa cells, confirming that this response was dependent on IFN-I signaling. 
To begin to dissect the mechanism by which IFN-I signaling regulates lysosome acidification and function, we first took a candidate-based approach and investigated IFITM3. This transmembrane ISG has antiviral activity and is thought to reside in the endosomal trafficking system and to interact with the lysosomal v-ATPase complex (Spence et al., 2019; Wee et al., 2012), suggesting a potential role for this protein in lysosome function. Immunofluorescence analysis revealed that IFITM3 co-localized with LAMP1, but not Rab5, confirming that IFITM3 is a lysosomal protein (Figure 4A). Remarkably, lysosomal pH in Ifitm3 KO cells was elevated in both basal and IFN $\beta$-primed conditions relative to WT cells, partially phenocopying the Ifnar2 $\mathrm{KO}$, and suggesting that IFITM3 contributes to IFN-I-meditated lysosomal remodeling (Figures 4B-D). Ifitm3's contribution to basal pH levels are consistent with the tonic activities of IFNs observed in diverse mammalian cell types (Schoggins et al., 2014). Ifitm3 KO cells were more resistant to Stm-induced cell death than the WT parental line both before and after IFN $\beta$ priming (Figure 4E), suggesting that this ISG contributes to IFN-I signaling augmentation of Stm cytotoxicity.

\section{Discovery of ISGs with novel roles in lysosomal $\mathrm{pH}$ regulation}

Given that both lysosomal $\mathrm{pH}$ and degradative activity in Ifitm3 $\mathrm{KO}$ cells were still somewhat sensitive to IFN $\beta$ priming (Figures 4C, D), we hypothesized that additional ISGs regulate lysosome function. To identify these factors, we employed organellar proteomics, a powerful and unbiased affinity-based technique that has not yet been applied to host-pathogen interactions. We used a recently described lysosomal pulldown system, LysoIP (Abu-Remaileh 
(Figure 5B). Spectral counts for IFITM3 were enriched in lysosomes from IFN $\beta$-treated cells,

We constructed KO cell lines for most of the lysosomally enriched ISGs and assessed their

Ifitm3 contributed to both basal and IFN-I-mediated lysosomal acidification (Figure 5C). In 
We hypothesized that IFN-I's role in lysosomal acidification might explain why IFN-I signaling

201 enhances Stm cytotoxicity because acidic $\mathrm{pH}$ is known to stimulate expression of

202 SPI-2-encoded and other virulence genes (Chakraborty et al., 2015; Prost et al., 2007).

203 Consistent with this idea, IFN $\beta$ priming increased intracellular Stm SPI-2 encoded gene

204 expression (Figures 6A and S5A). These genes were only induced after SCV formation (i.e.

205 later than one-hour post-infection), and the effect of IFN $\beta$ priming was eliminated in Ifnar2 $\mathrm{KO}$

206 cells. Furthermore, treatment with Bfa1 abolished IFN $\beta$ induction of SPI-2 expression (Figures

$2076 \mathrm{~A}$ and S5A), suggesting that diminished SCV acidification is the primary mechanism of

208 IFN-I-enhanced SPI-2 induction. Analyses of SPI-2 gene expression using flow cytometry and

209 a fluorescent $P_{s i f B}: \because g f p$ Stm reporter strain (Garmendia et al., 2003), confirmed this phenotype at

210 single bacterial cell resolution (Figure 6B). Similar expression trends were also observed in

211 known acid-induced, virulence-associated genes that are not encoded within SPI-2, such as

212 pagD (Gunn et al., 1995) (Figures 6C and S5B, C). This is consistent with the observation

213 above (Figure 2A) that SPI-2-deficient Stm retain some cytotoxicity. Importantly, the

214 expression of SPI-1 genes, which encode invasion-specific functions, was not altered in

215 infections with IFN $\beta$ priming or in Ifnar2 $\mathrm{KO}$ cells (Figures 6D and S5D). Together, these data

216 indicate that IFN-I-mediated acidification of lysosomes promotes intracellular Stm virulence

217 gene expression.

218 The Stm virulence program can lead to the breakage of SCV, exposing the pathogen to the

219 host cytosol (Roy et al., 2004; Xu et al., 2019). To assess whether the pathogen was

220 cytosol-exposed, infected cells were treated with high concentrations of gentamicin, an 
221

222

223

224

225

226

227

228

229

230

231

232

233

234

235

236 237 promotes Stm pathogenicity in IECs.

238

239

240

241

antibiotic that can penetrate into cells at high concentrations (Myrdal et al., 2005). Stm in

IFN $\beta$-treated WT cells were markedly more sensitive to gentamicin than bacteria in IFN $\beta$-treated Ifnar2 KO cells (Figure 6E), suggesting that IFN-I activation of Stm virulence gene expression promotes SCV rupture and facilitates the pathogen's access to the cytosol. Consistent with this idea, $\sim 60 \%$ of Stm stained positive for galectin-3, a marker of SCV damage (Thurston et al., 2012), in infected IFN $\beta$-primed WT HeLa cells, whereas <20\% of Stm were galectin-3+ in infected Ifnar2 $\mathrm{KO}$ cells (Figures 6F, G). Together, these data suggest a model that explains why IFN-I signaling was a hit in the CRISPR/Cas9 screen: IFN-I signaling-dependent lysosome acidification stimulates intracellular Stm virulence gene expression, which promotes SCV rupture and subsequent Stm-induced cytotoxicity.

\section{IFN-I promotes epithelial Stm pathogenesis in vivo}

To understand the function of IFN-I signaling in Stm pathogenesis, we used a more physiologic culture system - primary human-derived small intestinal organoids. IFN $\beta$ priming of organoids increased cell death associated with Stm infection, whereas treatment of organoids with pyridone-6 had the opposite effect (Figures 7A, B), supporting the idea that IFN-I signaling

To further dissect the importance of IFN-I signaling in the context of in vivo Stm infection, we used bone marrow transfers to generate chimeric C57BL/6 mice that had Ifnarl deleted in only the hematopoietic compartment or in other bodily tissues, including epithelial surfaces

(Figure S6A-C). Following intraperitoneal delivery of poly (I:C) to induce IFN $\beta$ production 
242 (Lauterbach et al., 2010), chimeric mice were oro-gastrically inoculated with Stm to assess the

243 roles of epithelial and hematopoietic compartments in resistance to infection (Figure 7C).

244 Strikingly, mice with KO epithelium and WT bone marrow were relatively resistant to oral Stm

245 infection, with reduced weight loss and distal organ bacterial loads compared to mice that had

246 WT epithelium and bone marrow (Figures 7D, E), suggesting that IEC IFN-I signaling

247 enhances Stm pathogenicity during infection. We also observed a similar phenotype in mice

248 with WT epithelium and $\mathrm{KO}$ bone marrow (Figures 7D, E), consistent with previous

249 observations that immune cell IFN-I signaling also promotes Stm pathogenesis (Robinson et al.,

250 2012). Mice that had both KO epithelium and bone marrow were more protected than either

251 chimera (Figures 7D, E), further supporting the idea that Stm takes advantage of IFN-I

252 signaling in both the gut epithelium as well as in bone marrow-derived cells.

Although histological analyses revealed similar levels of tissue damage in both chimeras

254 (Figures 7F, G), finer-scale immunofluorescence studies with TUNEL staining to quantify cell

255 death showed that TUNEL+ (dying) cells tracked with the WT compartment. In chimeric mice

256 with WT epithelium, TUNEL staining primarily co-localized with E-cadherin-positive IECs

257 (Figures 7H, I). In contrast, in Stm-infected chimeric mice with WT bone marrow, cell death

258 was primarily localized to E-cadherin-negative cells in the lamina propria (Figures $7 \mathrm{H}, \mathrm{I}$ ).

259 Together, these in vivo studies suggest that IFN-I signaling in the epithelial compartment

260 facilitates Stm-induced IEC death and pathogen spread. 
279 acidification processes by directly modulating the proton concentration gradient. However, 
Previous studies have linked Cnp with not only lysosomal, but mitochondrial compartments

(McFerran and Burgoyne, 1997), raising the possibility that ISG function in additional cell infection in bone-marrow derived immune cells. Such mechanisms include elevated 

stimulates and exploits IFN-I signaling as part of its pathogenic strategy.

Our finding that IFN-I signaling governs the composition and function of the lysosome

316 provides a new cell biologic perspective for understanding cytokine function. It will be of

317 interest to determine whether other immune signals (i.e. including other IFNs and cytokines)

318 can also direct remodeling of lysosomes and other organelles, such as the mitochondria and

319 endoplasmic reticulum, under homeostasis and in diverse pathogenic contexts. Such activities

320 may constitute a broadly applicable lens through which to view and enhance our understanding

321 of the cell biology of innate defense. 


\section{AUTHORCONTRIBUTIONS}

323 H.L.Z. and M.K.W. conceived and all authors designed the study. H.L.Z., A.Z., and X.L.

324 performed all experiments and analyzed data. H.L.Z., B.S., and M.K.W. wrote the manuscript 325 and all authors edited the paper.

327 ACKNOWLEDGEMENTS

328 We thank members of the Waldor lab for helpful discussions on all aspects of this project, Dr.

329 David Breault at the Harvard Digestive Diseases Center (HDDC) Organoid Core for the 330 primary human small intestine organoids; and Michal Pyzik from Dr. Richard Blumberg's lab 331 for assistance in creation of bone marrow chimeric mice.

332 Research in the M.K.W. laboratory is supported by HHMI and NIH grant R01 AI-042347. A.Z.

333 was supported by an EMBO long-term fellowship (ALTF 1514-2016) and by a HHMI 334 Fellowship of the Life Sciences Research Foundation.

337 The authors declare no competing interests. 
(A) Workflow for CRISPR/Cas9 Stm cytotoxicity screen in HT29-Cas9 cells.

(C) Cytoscape visualization of enriched pathways. dashed red circle.

(E) Overview of IFN-I signaling pathway. Numbers correspond to hit ranks in each library.

\section{Figure 2. IFN-I promotes Stm cytotoxicity in IECs}

(A) Survival of IFN $\beta$-primed or unprimed WT or Ifnar2 KO HT29 cells 4 hours post WT or mutant Stm infection. Mean \pm s.d., $\mathrm{n}=3$.

(B) Survival of mock or drug-treated WT HT29 cells 20 hours post WT Stm infection. Mean \pm

s.d., $n=3$.

(C) Flow cytometry of IFN $\beta$-primed or unprimed WT and Ifnar2 KO HT29 cells 20 hours post

(E) Representative images of LAMP1-RFP-expressing HeLa cells 4 hours post GFP-Stm infection. Boxed insets depict higher magnification showing bacterial colocalization with 
LAMP1-RFP. Scale bar, $10 \mu \mathrm{m}$.

(F) Quantification of LAMP1-RFP-positive Stm from 10 fields. Mean \pm s.d., $\mathrm{n}=3$.

Statistical analysis was performed by two-tailed Student's $t$ test $(* \mathrm{P}<0.05, * * \mathrm{P}<0.01$ and

$* * * \mathrm{P}<0.001)$.

See also Figure S1, 2 and Table S1.

\section{Figure 3. IFN-I signaling regulates lysosomal positioning, acidity, and protease activity}

(A) Representative images of lysosome (LAMP1-GFP+/LysoTracker+ compartment) distribution in WT and Ifnar2 KO HeLa cells with or without 16 hours of IFN $\beta$ stimulation. Nuclei (blue) were stained with DAPI and actin (purple) was stained with phalloidin. Scale bar, $5 \mu \mathrm{m}$.

(B) Quantification of perinuclear lysosome indices from 10 cells. Mean \pm s.d., $\mathrm{n}=3$.

(C-D) Flow cytometry of LysoTracker Red (C) and DQ-Green BSA fluorescence (D) in HeLa cells \pm 16 hours of treatment with IFN $\beta$ or the lysosomal acidification inhibitor Bfa1. Vertical dashed lines indicate the mean fluorescence value of the mock control in WT (red) or Ifnar2 KO (blue) cells.

(E) Relative cathepsin D activity in WT and Ifnar2 KO HeLa cells \pm 16 hours of IFN $\beta$ treatment. Mean \pm s.d., $\mathrm{n}=5$.

Statistical analysis was performed by two-tailed Student's $t$ test $(* * * \mathrm{P}<0.001)$.

See also Figure S3. 
(A) Representative images of LAMP1-RFP or Rab5-RFP-expressing HeLa cells stained with infection. Mean \pm s.d., $\mathrm{n}=3$.

Statistical analysis was performed by two-tailed Student's $t$ test $(* \mathrm{P}<0.05$, $* * \mathrm{P}<0.01$ and

$* * * \mathrm{P}<0.001)$

\section{Figure 5. Discovery of ISGs with novel roles in lysosomal pH regulation}

394 (A) Immunoblotting for known (LAMP1, CTSD) and suspected (IFITM3) lysosomal proteins

(B) Relative fold change scatterplot of protein abundance in lysosomes purified from WT or

401 Statistical analysis was performed by two-tailed Student's $t$ test $(* \mathrm{P}<0.05$, **P $<0.01$ and 
$* * * \mathrm{P}<0.001)$

See also Figure S4 and Table S2.

\section{Figure 6. IFN-I signaling promotes Stm virulence gene expression and SCV rupture}

Relative induction of SPI-2 (ssaV) (A), PhoP-induced virulence gene (pagD) (C) and SPI-1 infection. Scale bar, $10 \mu \mathrm{m}$.

(G) Quantification of the Gal3 positive SCVs from 10 cells. Mean \pm s.d., $\mathrm{n}=3$.

See also Figure S5. 
423 cell death. Scale bar, $100 \square \mu \mathrm{m}$.

424 (B) Enteroid survival 20 hours post WT Stm infection. Mean \pm s.d., $\mathrm{n}=3$.

425 (C) Timeline of generation (top) and oral Stm infection (bottom) of Ifnarl chimeric mice.

426 (D) Body weights of Stm-infected chimeric mice. Mean \pm s.e.m., $\mathrm{n}=12$ mice.

427 (E) Liver and spleen Stm CFU burdens from chimeric mice 5 days post-Stm infection. Mean \pm

428 s.d., $\mathrm{n}=12$ mice.

429 (F) Representative H\&E stained ileal sections from chimeric mice 5 days post-Stm infection.

430 Scale bars, $100 \mu \mathrm{m}$.

431 (G) Average histological scores of chimeric mice 5 days post-Stm infection from 8 fields. Mean

$432 \pm$ s.d., $\mathrm{n}=4$ mice.

433 (H) Representative images of ileal sections from chimeric mice 5 days post-Stm infection. IECs

434 were identified with E-cadherin (red), dying cells with TUNEL (green), and nuclei with DAPI

435 (blue). The white dashed line marks the epithelial surface. Scale bar, $100 \mu \mathrm{m}$.

436

(I) Quantification of TUNEL+/E-cadherin+ (red) or TUNEL+/E-cadherin- (blue) cells per field

437 from 8 fields. Mean \pm s.d., $\mathrm{n}=4$ mice.

438 Statistical analysis was performed by two-tailed Student's $t$ test in (B) and (G). Statistical 439 analysis was performed by two-tailed Mann-Whitney U-test in (D) and (E). (*P $<0.05$, **P $<$ $440 \quad 0.01$ and $* * * \mathrm{P}<0.001)$.

441 See also Figure S6. 


\section{Figure S1. IFN-I promotes intracellular Stm cytotoxicity, Related to Figure 2} mutant Stm infection. Mean \pm s.d., $\mathrm{n}=3$.

(D) Quantification of flow cytometry data in Figure 2C. Mean \pm s.d., $n=4$.

(F) Quantification of flow cytometry data from Figure S2E. Mean \pm s.d., $n=4$.

454 Statistical analysis was performed by two-tailed Student's $t$ test $(* \mathrm{P}<0.05$, **P $<0.01$ and

$* * * \mathrm{P}<0.001)$

Figure S2. IFN-I does not affect Stm invasion or SCV formation, Related to Figure 2

458 (A) Flow cytometry of IFN $\beta$-primed WT and Ifnar2 KO HT29 cells 4 hours post mCherry-Stm

459 infection. Quantification is shown in Figure 2D.

460 (B) Representative images of Rab5-RFP-expressing HeLa cells at 4 hours post GFP-Stm 461 infection. Scale bar, $10 \mu \mathrm{m}$.

(C) Quantification of Rab5-RFP-positive Stm from 10 fields. Mean \pm s.d., $n=3$. 
463 (D) Representative images of Rab7-RFP-expressing HeLa cells 4 hours post GFP-Stm infection.

464 Scale bar, $10 \mu \mathrm{m}$.

465 (E) Quantification of Rab7-RFP-positive Stm from 10 fields. Mean \pm s.d., $\mathrm{n}=3$.

Figure S3. IFN-I signaling regulates lysosomal remodeling in both epithelial cell and

\section{THP1 cells, Related to Figure 3}

469

(A) Quantification of mean fluorescence intensity (MFI) from Figure 3C. Mean \pm s.d., $n=3$.

470

(B) Flow cytometry of LysoSensor staining in WT and Ifnar2 KO HeLa cells \pm 16 hours of

471

IFN $\beta$ treatment.

472

(C) Flow cytometry of LysoTracker staining in HT29 cells \pm 16 hours of drug treatment.

473

(D) Quantification of mean fluorescence intensity from Figure 3D. Mean \pm s.d., $n=3$.

474

(E) Flow cytometry of Dextran-568 uptake in WT and Ifnar2 KO HeLa cells \pm 16 hours of

IFN $\beta$ treatment.

476

(F) Flow cytometry of LysoTracker staining in monocytic macrophage-like THP1 cells \pm 16

477 hours of IFN $\beta$ treatment.

478 Statistical analysis was performed by two-tailed Student's $t$ test $(* * \mathrm{P}<0.01$ and ***P $<0.001)$.

479

Figure S4. Purity of isolated lysosomes and IFITM3 gene KO in HeLa cells, Related to

\section{Figure 5}


485 Figure S5. Intracellular Stm virulence gene expression, Related to Figure 6

486 (A-D) Relative induction of individual SPI-2 (A), PhoP-induced (B), SPI-3 (C) or SPI-1 (D)

487 genes in intracellular Stm from WT and Ifnar2 KO HeLa cells \pm drug treatment. Data are

488 normalized to transcript levels from LB-cultured Stm (red). Mean \pm s.d., $n=3$.

489 Statistical analysis was performed by two-tailed Student's $t$ test $(* * * \mathrm{P}<0.001)$.

490

491

Figure S6. Generation of chimeric mice by bone marrow transfer, Related to Figure 7

492 (A-C) Flow cytometry of peripheral blood CD45.1 and CD45.2+ cells in mock and chimeric 493 mice 4 weeks after bone marrow transplantation. WT mock mice carry CD45.2 allele but not

494 CD45.1 (A), which is abolished by irradiation (B, C). 4 weeks later after CD45.1 BM transfer, 495 the chimeric mice carry CD45.1 allele but not CD45.2 (B, C).

496

497 
STAR METHODS

KEY RESOURCE TABLE

\begin{tabular}{|c|c|c|}
\hline REAGENT or RESOURCE & SOURCE & IDENTIFIER \\
\hline \multicolumn{3}{|l|}{ Antibodies } \\
\hline LAMP1 (D4O1S) Mouse mAb & $\begin{array}{l}\text { Cell Signaling } \\
\text { Technology }\end{array}$ & $15665 S$ \\
\hline Anti-IFIT3/P60 antibody [OTI1G1] & Abcam & ab118045 \\
\hline IFITM3 Antibody & Proteintech & 11714-1-AP \\
\hline Cathepsin D Monoclonal Antibody (CTD-19) & ThermoFisher & MA1-26773 \\
\hline Anti-GM130 antibody [EP892Y] - cis-Golgi Marker & Abcam & ab52649 \\
\hline$\beta$-Actin Antibody (AC-15) & Santa Cruz & sc-69879 \\
\hline PE/Cy7 anti-mouse CD45.2 & Biolegend & 109829 \\
\hline FITC anti-mouse CD45.1 & Biolegend & 110706 \\
\hline Human/Mouse E-Cadherin Antibody & $R \& D$ & AF748 \\
\hline Anti-Rabbit IgG (whole molecule)-Peroxidase antibody & Sigma & A4914 \\
\hline Goat anti-Mouse IgG $(\mathrm{H}+\mathrm{L})$ Secondary Antibody, HRP & ThermoFisher & 31430 \\
\hline $\begin{array}{l}\text { Rabbit anti-Goat lgG }(\mathrm{H}+\mathrm{L}) \text { Cross-Adsorbed Secondary } \\
\text { Antibody, HRP }\end{array}$ & Invitrogen & $R-21459$ \\
\hline $\begin{array}{l}\text { Donkey anti-Goat lgG }(\mathrm{H}+\mathrm{L}) \text { Cross-Adsorbed Secondary } \\
\text { Antibody, Alexa Fluor } 568\end{array}$ & Invitrogen & A-11057 \\
\hline $\begin{array}{l}\text { Goat anti-Rabbit lgG }(\mathrm{H}+\mathrm{L}) \text { Highly Cross-Adsorbed } \\
\text { Secondary Antibody, Alexa Fluor } 488\end{array}$ & Invitrogen & A-11034 \\
\hline \multicolumn{3}{|l|}{ Bacterial Strains } \\
\hline Salmonella Typhimurium SL1344 & Dr. Dirk Bumann & \\
\hline Salmonella Typhimurium SL1344 $\Delta \mathrm{prgH}$ & This study & \\
\hline Salmonella Typhimurium SL1344 $\Delta$ ssaV & This study & \\
\hline Salmonella Typhimurium SL1344-eGFP & This study & \\
\hline Salmonella Typhimurium SL1344-mCherry & This study & \\
\hline Salmonella Typhimurium SL1344- $P_{\text {sifi }}$-GFP & Dr. Dirk Bumann & \\
\hline Salmonella Typhimurium SL1344-mCherry- $\mathrm{P}_{\text {siti }}$-GFP & This study & \\
\hline One Shot Stbl3 Chemically Competent E. coli & $\begin{array}{l}\text { Thermo Fisher } \\
\text { Scientific }\end{array}$ & Cat No.C737303 \\
\hline \multicolumn{3}{|l|}{ Chemicals and Recombinant Proteins } \\
\hline IFN $\beta$ & Peprotech & Cat No. 300-02BC \\
\hline pyridine- 6 & BioVision & Cat No. 2534 \\
\hline Ruxolitinib (NCB018424) & Selleckchem & Cat No.S1378 \\
\hline Polybrene, & Sigma & Cat No. TR-1003-G \\
\hline Trizol & Invitrogen & Cat No. 15596018 \\
\hline
\end{tabular}




\begin{tabular}{|c|c|c|}
\hline SuperScript III reverse transcriptase & Invitrogen & Cat No. 18080085 \\
\hline Roche $2 \times S Y B R$ master mix & Roche & $\begin{array}{l}\text { Cat No. } \\
04707516001\end{array}$ \\
\hline BfA1 & SantaCruz & Cat No. sc-201550 \\
\hline \multicolumn{3}{|l|}{ Critical Commercial Assays } \\
\hline Blood and Cell Culture DNA MaxiKit & QIAGEN & Cat No. 13362 \\
\hline TransIT-LT1 & Mirus & Cat No. MIR230 \\
\hline QIAquick Gel Extraction Kit & Qiagen & Cat No. 28704 \\
\hline LDH assay kit & Promega & Cat No. G1780 \\
\hline FITC Annexin V Apoptosis Detection kit & BioLegend & Cat No. 640922 \\
\hline Lipofectamine 3000 & ThermoFisher & Cat No. L3000008 \\
\hline Lysotracker & ThermoFisher & Cat No. L7528 \\
\hline Lysosensor & Thermofisher & Cat No. L7545 \\
\hline fluorogenic peptide substrate of cathepsin $D$ & Biovision & Cat No. K143 \\
\hline Dextran 568 & ThermoFisher & Cat No. D22912 \\
\hline DQ-Red BSA & ThermoFisher & Cat No. D12050 \\
\hline $10 \%$ Tris-Glycine gels & ThermoFisher & $\begin{array}{l}\text { Cat No. } \\
\text { XP00102BOX }\end{array}$ \\
\hline nitrocellulose membranes & Invitrogen & Cat No. IB23002 \\
\hline $\begin{array}{l}\text { SuperSignal West Pico Enhanced Chemiluminescence } \\
\text { kit }\end{array}$ & ThermoFisher & Cat No. 34577 \\
\hline PureLink Micro-to-Midi total RNA purification system & Invitrogen & Cat No. 12183 \\
\hline Ambion Turbo DNA-free DNase & Invitrogen & Cat No. AM1907 \\
\hline TUNEL kit & ThermoFisher & Cat No. A23210 \\
\hline \multicolumn{3}{|l|}{ Experimental Models: Cell Lines } \\
\hline HeLa & ATCC & CRM-CCL-2, female \\
\hline HEK293T & ATCC & CRL-3216, female \\
\hline HT29 & ATCC & HTB-38, female \\
\hline THP-1 & ATCC & TIB-202, male \\
\hline Primary human small intestine organoids & $\begin{array}{l}\text { Harvard Digestive } \\
\text { Diseases Center } \\
\text { Organoid Core }\end{array}$ & $\begin{array}{l}\text { Gift from Dr. David } \\
\text { Breault }\end{array}$ \\
\hline \multicolumn{3}{|l|}{ Experimental Models: Organisms/Strains } \\
\hline Mouse: C57BL/6J B6(Cg)-Ifnar1tm1.2Ees/J & $\begin{array}{l}\text { The Jackson } \\
\text { Laboratory }\end{array}$ & Stock No: 028288 \\
\hline Mouse: B6.SJL-Ptprca Pepcb/BoyJ & $\begin{array}{l}\text { The Jackson } \\
\text { Laboratory }\end{array}$ & Stock No: 002014 \\
\hline \multicolumn{3}{|l|}{ Oligonucleotides } \\
\hline \multicolumn{3}{|l|}{ qPCR primers, see Table S3 } \\
\hline CRISPR gene KO primers, see Table S4 & & \\
\hline
\end{tabular}




\begin{tabular}{|c|c|c|}
\hline \multicolumn{3}{|l|}{ Recombinant DNA } \\
\hline lentiGuide-Puro & Addgene & 52963 \\
\hline psPAX2 & Addgene & 12260 \\
\hline pMD2.G & Addgene & 12259 \\
\hline pLJC5-LAMP1-RFP-3xHA & Addgene & 102932 \\
\hline pHR-FKBP:mCherry-Rab5a & Addgene & 72901 \\
\hline pHR-FKBP:mCherry-Rab7a & Addgene & 72903 \\
\hline LAMP1-mGFP & Addgene & 34831 \\
\hline pLJC5-Tmem192-3xHA & Addgene & 102930 \\
\hline mAG-GAL3 & Addgene & 62734 \\
\hline \multicolumn{3}{|l|}{ Software and Algorithms } \\
\hline Primer3 & $\begin{array}{l}\text { Untergasser et al., } \\
2012\end{array}$ & http://primer3.ut.ee/ \\
\hline ImageJ & $\mathrm{NIH}$ & $\begin{array}{l}\text { https://imagej.nih.go } \\
\text { v/ij/download.html }\end{array}$ \\
\hline FlowJo 10.2 & FlowJo & $\begin{array}{l}\text { https:/www.flowjo.co } \\
\text { m/solutions/flowjo. }\end{array}$ \\
\hline GraphPad Prism & GraphPad Software & $\begin{array}{l}\text { https://www.graphpa } \\
\text { d.com. }\end{array}$ \\
\hline Gene set enrichment Analysis & Broad Institute & $\begin{array}{l}\text { http://www.broadinsti } \\
\text { tute.org/gsea. }\end{array}$ \\
\hline DAVID analysis & NIAID/NIH & $\begin{array}{l}\text { http://david.abcc.ncif } \\
\text { crf.gov }\end{array}$ \\
\hline
\end{tabular}

CONTACT FOR REAGENT AND RESOURCE SHARING

502 Further information and requests for resources and reagents should be directed to and will be

503 fulfilled by the Lead Contact, Matthew K Waldor (mwaldor@ research.bwh.harvard.edu)

EXPERIMENTAL MODEL AND SUBJECT DETAILS

\section{Bacterial strains, plasmids, and antibodies}

508 Strains, plasmids, oligonucleotides and antibodies used in this study are listed in key resources 
table and table S3, 4. Escherichia coli $\mathrm{K}-12 \mathrm{DH} 5 \alpha \lambda$ pir was used for cloning procedures and

\section{Cell lines}

HeLa (ATCC, Cat No. CRM-CCL-2, female) and HEK293T (ATCC, Cat No. CRL-3216,

519 female) cells were cultured in Dulbecco's modified Eagle's medium (DMEM; ThermoFisher,

522 (Thermo Fisher, Cat No. 30-2007) supplemented with 10\% FBS. THP-1 (ATCC, Cat No.

523 TIB-202, male) cells were cultured in RPMI-1640 medium (Lonza, Cat No. 12-167F) with 10\%

524 non-heat inactivated FBS (GeminiBio, Cat NO. 100-500) and supplemented with HEPES

525 (Lonza, Cat No. 17-737E), 2-Mercaptoethanol (Invitrogen, Cat No. 21985023) and

526 L-Glutamine (Lonza, Cat No. 17-605E). All cells were cultured at $37^{\circ} \mathrm{C}$ in a $5 \% \mathrm{CO}_{2}$ incubator. 
529 Primary human small intestine organoids (enteroids) were kindly provided by Dr. David Breault at the Harvard Digestive Diseases Center (HDDC) Organoid Core. Enteroids were cultured in the following medium: advanced DMEM/F12 (Gibco, Cat No.12634-028) supplemented with plate was centrifuged for 5 mins at $300 \times \mathrm{g}$ before it was placed in a $37^{\circ} \mathrm{Cincubator}$ for $30 \mathrm{mins}$.

545 After infection, enteroids were transferred to microcentrifuge tubes, spundown, mixed with 
enteroids before imaging. To quantitatively measure cell death, the media from each well/sample was also assayed for LDH activity as described above. LDH release values of mock treated samples were set at 1 for normalization.

\section{Bone marrow chimera mice}

555 C57BL/6 and Ifnarl ${ }^{-/}$mice were purchased from The Jackson Laboratory (Bar Harbor, ME, USA) and were maintained on a 12-hour light/dark cycle and a standard chow diet at the

$5641 \square$ day before injection of bone marrow from WT or Ifnar $1^{-/-}$mice. Bone marrow was extracted

565 from femurs of donor mice by flushing with PBS and then washed once in PBS; $1 \times 10^{6}$ cells point engraftment was evaluated by flow cytometry.

\section{Infection of chimeric mice}

$57020 \mu \mathrm{g}$ poly (I:C) (Sigma, Cat No. P1530) was given intraperitoneally to chimeric mice one day 
571 before Stm infection and every other day for a total of 3 doses to stimulate IFN production.

572 Food was withdrawn for 4 hours before infection. Stm inocula were prepared as described

573 above. Mice were infected orogastrically with $5 \square \times \square 10^{8} \mathrm{Stm}$ in $100 \mu \mathrm{PBS}$. Food was returned

574 to the cages 2 hpi. Infected mice were sacrificed 5 days after infection. Tissue samples of the

575 small intestine, spleen and liver were collected for histological analysis and enumeration of

576 colony-forming units (CFU). CFU were quantified by serial-dilution plating of homogenized

577 tissue samples on LB plates containing $100 \mu \mathrm{g} / \mathrm{ml}$ streptomycin.

METHOD DETAILS

\section{Pharmacologic inhibitors and IFN $\beta$ priming}

JAK inhibitors pyridine-6 (BioVision, Cat No. 2534) and ruxolitinib (NCB018424)

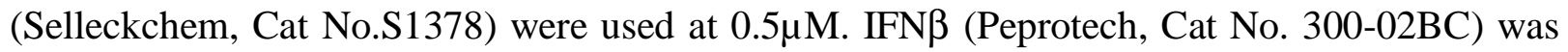

used at $10 \mathrm{ng} / \mathrm{ml}$ for cell priming. Drug-treated cells were primed for 16 hours (unless otherwise indicated) before Stm infection.

\section{Stm infections}

All tissue culture infections were done according to the following procedure unless otherwise indicated. WT and mutant Stm were grown for $\sim 16$ hours at $37^{\circ} \mathrm{C}$ with shaking and then sub-cultured (1:33) in LB without antibiotics for 3 hours until the cultures reached an $\mathrm{OD}_{600}$ of 
resuspended in DMEM without FBS, and an appropriate volume of bacterial solution was

\section{CRISPR/Cas9 Stm infection screen}

600

601

602

603

604

605

606

607

608

609

610

611

recovery of survivor cells; when $70 \%$ confluency was achieved, cells were trypsinized, pooled,

HT29-Cas9 CRISPR libraries were constructed as described previously (Blondel et al., 2016)

using the Avana sgRNA library, which contains four different sgRNAs targeting each human protein-coding gene (Doench et al., 2016). For each library, two sets of four T225 flasks

(Corning, Cat No. 14-826-80) were seeded with $15 \times 10^{6}$ cells per flask and then incubated for

48 hours. At the time of the screen, there were $\sim 150 \times 10^{6}$ cells per experimental condition, corresponding to $\sim 2,000 \times$ coverage per sgRNA. Cells were at $\sim 70 \%$ confluence at the time of infection. The infection was done as described above with minor modifications. Briefly, HT29 libraries were infected with WT Stm at an MOI of 300 for $30 \mathrm{~min}$. After infection, the libraries were expanded in McCoy's 5A + FBS containing $5 \mu \mathrm{g} / \mathrm{ml}$ gentamicin, to both permit intracellular bacterial cytotoxicity and minimizethe intracellular gentamicin concentration to allow Stm invasion during the next round of infection. Flasks were checked daily to monitor and reseeded for the next round of infection. In total, four rounds of infection were conducted. 
613 Surviving cells from the last round of infection were used for preparation of genomic DNA.

614

615

616

617

618

619

620

621

622

623

624

625

626

627

628

629

630

631

632

633

\section{Genomic DNA preparation, sequencing, and analyses of screen results}

Genomic DNA was obtained from $75 \times 10^{6}$ cells after positive selection, as well as from input cells, using the Blood and Cell Culture DNA MaxiKit (QIAGEN, Cat No. 13362). sgRNA sequences was amplified by PCR as described (Doench et al., 2016). The read counts were first normalized to reads per million within each condition by the following formula: reads per sgRNA / total reads per condition $\times 10^{6}$. Reads per million were then $\log _{2}$-transformedby first adding 1 to all values, in order calculate the $\log$ of $\operatorname{sgRNAs}$ with zero reads. The $\log _{2}$ fold-change of each sgRNA was then determined relative to the input sample for each biological replicate. MAGeCK analysis for genome-scale CRISPR-Cas9 knockout screens was used to evaluate the rank and statistical significance of perturbations from the ranked list (Li et al., 2014) and enriched pathways were determined using ClueGo (Bindea et al., 2009).

\section{Lentivirus preparation and transductions}

The Galectin 3, Rab5, Rab7, LAMP1, and LC3B lentiviral expression plasmids used in the study are listed in Table S4. Lentiviral packaging plasmids psPAX2 and pVSV-G, and the corresponding cargo plasmid were transfected into 293T cells with the TransIT-LT1 transfection reagent (Mirus, Cat No. MIR230). 48 hours following transfection, 293T culture supernatants were harvested, passed through a $0.45 \mu \mathrm{m}$ pore filter, and added to target cells that were grown to $70-80 \%$ confluency in 6-well plates. Polybrene (Sigma, Cat No. TR-1003-G) $(8 \mu \mathrm{g} / \mathrm{ml})$ was 
634 added and the 6-well plates were spun at $1000 \times \mathrm{g}$ for 2 hours at $30^{\circ} \mathrm{C}$, after which cells were returned to $37^{\circ} \mathrm{C}$. The infections were repeated the next day with supernatants from 72 hour-transfected $293 \mathrm{~T}$ cultures.

\section{Construction of cell lines with targeted gene disruptions}

The sgRNA sequences used for construction of targeted HT29-Cas9 and HeLa-Cas9 mutant cell 


\section{Cell survival assays}

656 For cell survival assays, $5 \times 10^{4}$ HT29 cells were seeded into 96-well plates and primed with or 657 without drugs in McCoy's 5Amedium supplemented with 10\% FBS.HT29 cells were infected with Stms trains at an MOI of 100 as described above. Cell survival analysis was performed using an LDH assay (Promega, Cat No. G1780) according to the manufacturer's protocol at 4 and 20 hpi.

661

\section{Stm invasion assays}

mCherry-or GFP-tagged Stm were used in all flow cytometry and immunofluorescence

with a LSR II (BD Bioscience) or SH800 (Sony) flow cytometer. Data were processed with

667 FlowJo software (v10.6.1).

668

\section{Annexin V staining and FACS analysis}

670 Cell death was detected with the FITC Annexin V Apoptosis Detection kit (BioLegend, Cat No.

673 buffer at $1 \times 10^{7}$ cells $/ \mathrm{ml}$ and mixed with $5 \mu \mathrm{l}$ of FITC-conjugated Annexin V. After incubation at 674 room temperature (RT) for $15 \square \mathrm{min}$ in the dark, $400 \mu \mathrm{l}$ of Annexin V binding buffer was added 675 and stained cells were immediately analyzed by flow cytometry as described above. 


\section{Immunofluorescence microscopy of tissue cultured cells}

HeLa cells were seeded in 12-well plates on $18 \mathrm{~mm}$ glass coverslips or 6-well chambers

(Mat-TEK, Cat No.P06G-1.5-10-F). Cells were transiently transfected with LAMP1-GFP

for 16 hours before infection with fluorescently-labeled Stm at an MOI 50. Live cells were

analyzed at 2 hpi by confocal microscopy to detect localization of Gal3 and Stm.

\section{Quantification of lysosome distribution}

Lysosome distribution was analyzed as described ( $\mathrm{Li}$ et al., 2016); the area occupied by nuclei 


\section{Measurement of lysosome acidity}

Cells with no treatment or with either $10 \mathrm{ng} / \mathrm{ml}$ IFN $\beta$ or $5 \mathrm{nM}$ BfA1 (SantaCruz, Cat No.

701 (Thermofisher, Cat No. L7545) for $15 \mathrm{~min}$ and washed with PBS. The fluorescence intensity of the stained cells was determined by flow cytometry.

\section{Cathepsin D activity assay}

HeLa cells were seeded in 96-well plates with or without $10 \mathrm{ng} / \mathrm{ml}$ IFN $\beta$ priming for 16 hours. A in triplicate and normalized to a standard curve.

\section{Endocytosis and lysosome function assays}

712 HeLa cells were seeded in 24 -well plates with or without $10 \mathrm{ng} / \mathrm{ml}$ IFN $\beta$ priming. Cells were 
718 LysoIP was performed largely as described (Abu-Remaileh et al., 2017). Briefly, pLJC5-3×HA-TMEM192 was used to introduce a lysosomal tag protein in WT and Ifnar2 KO

720

721

722

723

724 quantitative proteomics.

HeLa cells. 15 million cells were used for each replicate. Cells were rinsed twice with pre-chilled PBS and then scraped in $1 \mathrm{ml}$ of PBS containing protease and phosphatase inhibitors and pelleted at $100 \times \mathrm{g}$ for $2 \mathrm{~min}$ at $4^{\circ} \mathrm{C}$. Cells were resuspended in $950 \mu \mathrm{l}$ of the same buffer, and $25 \mu 1$ (equivalent to $2.5 \%$ of the total number cells) was reserved for further processing to generate the whole-cell sample. The remaining cells were gently homogenized with 25 strokes of a $2 \mathrm{ml}$ Dounce-type homogenizer. The homogenate was then centrifuged at $100 \times \mathrm{g}$ for $2 \mathrm{~min}$ at $4{ }^{\circ} \mathrm{C}$ to pellet the cell debris and intact cells, while cellular organelles including lysosomes remained in the supernatant. The supernatant was incubated with $150 \mu \mathrm{l}$ of anti-HA magnetic beads preequilibrated with PBS on a rotator shaker for 3 min. Immunoprecipitates were then gently washed three times with PBS on a DynaMag Spin Magnet. Beads with bound lysosomes were resuspended in $100 \mu 1$ pre-chilled $1 \%$ Triton-X lysis buffer to extract proteins. After 10 min incubation on ice, the beads were removed with the magnet. $5 \mu 1$ of each sample were subjected to $12.5 \%$-acrylamide SDS-PAGE and immunodetected using antibody listed in Table S6, while the remainder was submitted to the Thermo Fisher Center for Multiplexed Proteomics of Harvard Medical School (Boston, MA, USA) for Isobaric Tandem Mass Tag (TMT)-based

\section{Immunoblot analyses}

Mammalian cell lysates were prepared in radioimmuno-precipitation assay (RIPA) buffer 
Tris-Glycine gels (ThermoFisher, Cat No. XP00102BOX), and then transferred onto

\section{qRT-PCR quantification of Stm virulence gene expression}

750 Hela cells were seeded at $1.5 \times 10^{6}$ cells per 6-well plates. After drug-treatment for 16 hours, 
transcriptase (Invitrogen, Cat No. 18080085). cDNA was diluted 1:50 in $\mathrm{dH}_{2} \mathrm{O}$ and mixed with

Primer sequences are listed in Table S3. For data normalization, quadruplicate $\mathrm{C}_{t}$ values for

gene expression level of Stm in infection conditions was normalized to LB-cultured Stm.

\section{Flow cytometric analysis of Stm virulence gene expression}

HeLa cells were infected with mCherry-and sifB-GFP-expressing-Stm as described above. Cell control.

\section{Gentamicin protection assay}

778 Gentamicin protection assays were carried out as described (Knodler et al., 2014). Briefly,

779 HeLa cells in 96-well plates were infected in triplicate with Stm at an MOI of 50. Cells were 
781

782

783

784

785

786

787

788

789

790

791

792

793

794

795

796

797

798

799

800

801

min to eliminate extracellular bacteria. Then, media with either 10,100 or $400 \mu \mathrm{g} / \mathrm{ml}$ gentamicin

was applied to the cells. Cells were lysed $2 \mathrm{hpi}$ by washing three times with PBS and subsequent

incubation for 10 min with PBS containing $0.1 \%$ Triton X-100. Colony forming units (CFUs)

were enumerated by plating serial dilutions of the lysates onto LB plates with $100 \mu \mathrm{g} / \mathrm{ml}$

streptomycin. Data was normalized to the CFU of WT HeLa cells at gentamicin 10.

\section{Histology and tissue immunofluorescence}

Formalin-fixed, paraffin-embedded distal small intestinal samples sections of $4 \mu \mathrm{m}$ thickness

were mounted on glass slides and stained with hematoxylin and eosin. Histology score was

evaluated as described (Erben et al., 2014). For immunofluorescence analysis, distal small

intestinal samples were collected and flushed with PBS and fixed in $4 \%$ paraformaldehyde

(PFA) overnight at $4^{\circ} \mathrm{C}$ followed by washing with PBS. Tissues were embedded in Optimal

Cutting Temperature Compound (Tissue-Tek) and stored at $-80^{\circ} \mathrm{C}$ before sectioning on a

CM1860 UV cryostat (Leica). $6 \mu$ m-thick slides were stained with TUNEL (ThermoFisher, Cat

No. A23210) according to the manufacturer's instructions and then incubated with

anti-E-cadherin antibodies at $4^{\circ} \mathrm{C}$ overnight at a 1:200 in PBS. The next day, AF568-conjugated

secondary antibody, diluted at 1:500, was applied to the slides for 1 hour. Nuclei were stained

with DAPI at RT for 5 min in the dark. Samples were imaged with an Eclipse Ti confocal

microscope with a $20 \times \square$ objective (Nikon).

\section{QUANTIFICATION AND STATISTICAL ANALYSIS}


802 Statistical analyses were carried out using the two-tailed Student's $t$ test or one-way analysis of

803 variance (ANOVA) with Dunnet's post-correction on GraphPad Prism5.

804

805 DATA AND CODE AVAILABILITY

806 Original data for results of CRISPR screening is in Table S1, and original data for mass

807 spectrometry of lysosome proteomic is in Table S2.

808

809 Supplementary items

810 Table S1: CRISPR/Cas9 screening results, related to figure 1

811 Table S2: Mass spectrometry of lysosome proteomic, related to figure 3

812 Table S3: qPCR primers

813 Table S4: CRISPR KO primers

814

815 


\section{REFERENCES}

817 Abu-Remaileh, M., Wyant, G.A., Kim, C., Laqtom, N.N., Abbasi, M., Chan, S.H., Freinkman, E., and Sabatini, D.M.

818 (2017). Lysosomal metabolomics reveals V-ATPase- and mTOR-dependent regulation of amino acid efflux from

819 Iysosomes. Science 358, 807-813.

820 Bifulco, M., Laezza, C., Stingo, S., and Wolff, J. (2002). 2',3'-Cyclic nucleotide 3'-phosphodiesterase: a

821 membrane-bound, microtubule-associated protein and membrane anchor for tubulin. Proc Natl Acad Sci U S A 99,

822 1807-1812.

823 Bindea, G., Mlecnik, B., Hackl, H., Charoentong, P., Tosolini, M., Kirilovsky, A., Fridman, W.H., Pages, F., Trajanoski, Z., and Galon, J. (2009). ClueGO: a Cytoscape plug-in to decipher functionally grouped gene ontology and pathway annotation networks. Bioinformatics 25, 1091-1093.

Blondel, C.J., Park, J.S., Hubbard, T.P., Pacheco, A.R., Kuehl, C.J., Walsh, M.J., Davis, B.M., Gewurz, B.E., Doench, J.G., and Waldor, M.K. (2016). CRISPR/Cas9 Screens Reveal Requirements for Host Cell Sulfation and Fucosylation in Bacterial Type III Secretion System-Mediated Cytotoxicity. Cell host \& microbe 20, 226-237. Boxx, G.M., and Cheng, G. (2016). The Roles of Type I Interferon in Bacterial Infection. Cell host \& microbe 19, 760-769.

831 Butor, C., Griffiths, G., Aronson, N.N., Jr., and Varki, A. (1995). Co-localization of hydrolytic enzymes with widely disparate $\mathrm{pH}$ optima: implications for the regulation of lysosomal pH. J Cell Sci 108 ( Pt 6), 2213-2219.

833 Chakraborty, S., Mizusaki, H., and Kenney, L.J. (2015). A FRET-based DNA biosensor tracks OmpR-dependent acidification of Salmonella during macrophage infection. PLoS biology 13, e1002116.

835 Datsenko, K.A., and Wanner, B.L. (2000). One-step inactivation of chromosomal genes in Escherichia coli K-12 using PCR products. Proc Natl Acad Sci U S A 97, 6640-6645.

837 Desjardins, M., Celis, J.E., van Meer, G., Dieplinger, H., Jahraus, A., Griffiths, G., and Huber, L.A. (1994). Molecular characterization of phagosomes. J Biol Chem 269, 32194-32200.

839 Doench, J.G., Fusi, N., Sullender, M., Hegde, M., Vaimberg, E.W., Donovan, K.F., Smith, I., Tothova, Z., Wilen, C., Orchard, R., et al. (2016). Optimized sgRNA design to maximize activity and minimize off-target effects of CRISPR-Cas9. Nat Biotechnol 34, 184-191.

Erben, U., Loddenkemper, C., Doerfel, K., Spieckermann, S., Haller, D., Heimesaat, M.M., Zeitz, M., Siegmund, B., and Kuhl, A.A. (2014). A guide to histomorphological evaluation of intestinal inflammation in mouse models. Int J Clin Exp Pathol 7, 4557-4576.

845 Galan, J.E., Lara-Tejero, M., Marlovits, T.C., and Wagner, S. (2014). Bacterial type III secretion systems: specialized nanomachines for protein delivery into target cells. Annual review of microbiology 68, 415-438.

847 Garmendia, J., Beuzon, C.R., Ruiz-Albert, J., and Holden, D.W. (2003). The roles of SsrA-SsrB and OmpR-EnvZ in the regulation of genes encoding the Salmonella typhimurium SPI-2 type III secretion system. Microbiology 149,

$849 \quad 2385-2396$.

850 Geoghegan, J.L., and Holmes, E.C. (2018). The phylogenomics of evolving virus virulence. Nature reviews Genetics 851 19, 756-769.

852 Gonzalez-Navajas, J.M., Lee, J., David, M., and Raz, E. (2012). Immunomodulatory functions of type I interferons.

853 Nature reviews Immunology 12, 125-135.

854 Gunn, J.S., Alpuche-Aranda, C.M., Loomis, W.P., Belden, W.J., and Miller, S.I. (1995). Characterization of the 855 Salmonella typhimurium pagC/pagD chromosomal region. J Bacteriol 177, 5040-5047. 
Hautefort, I., Proenca, M.J., and Hinton, J.C. (2003). Single-copy green fluorescent protein gene fusions allow accurate measurement of Salmonella gene expression in vitro and during infection of mammalian cells. Appl Environ Microbiol 69, 7480-7491.

Hess, C.B., Niesel, D.W., and Klimpel, G.R. (1989). The induction of interferon production in fibroblasts by invasive bacteria: a comparison of Salmonella and Shigella species. Microb Pathog 7, 111-120.

Hos, N.J., Ganesan, R., Gutierrez, S., Hos, D., Klimek, J., Abdullah, Z., Kronke, M., and Robinson, N. (2017). Type I interferon enhances necroptosis of Salmonella Typhimurium-infected macrophages by impairing antioxidative stress responses. J Cell Biol 216, 4107-4121.

Hubel, P., Urban, C., Bergant, V., Schneider, W.M., Knauer, B., Stukalov, A., Scaturro, P., Mann, A., Brunotte, L., Hoffmann, H.H., et al. (2019). A protein-interaction network of interferon-stimulated genes extends the innate immune system landscape. Nature immunology 20, 493-502.

Hurley, D., McCusker, M.P., Fanning, S., and Martins, M. (2014). Salmonella-host interactions - modulation of the host innate immune system. Front Immunol 5, 481.

Hybiske, K., and Stephens, R.S. (2008). Exit strategies of intracellular pathogens. Nat Rev Microbiol 6, 99-110. Jo, E.K. (2019). Interplay between host and pathogen: immune defense and beyond. Experimental \& molecular medicine 51, 1-3.

Kernbauer, E., Maier, V., Rauch, I., Muller, M., and Decker, T. (2013). Route of Infection Determines the Impact of Type I Interferons on Innate Immunity to Listeria monocytogenes. PLoS One 8, e65007.

Knodler, L.A., Nair, V., and Steele-Mortimer, O. (2014). Quantitative assessment of cytosolic Salmonella in epithelial cells. PLoS One 9 , e84681.

Kovarik, P., Castiglia, V., Ivin, M., and Ebner, F. (2016). Type I Interferons in Bacterial Infections: A Balancing Act. Front Immunol 7, 652.

Kuhnl, A., Musiol, A., Heitzig, N., Johnson, D.E., Ehrhardt, C., Grewal, T., Gerke, V., Ludwig, S., and Rescher, U. (2018). Late Endosomal/Lysosomal Cholesterol Accumulation Is a Host Cell-Protective Mechanism Inhibiting Endosomal Escape of Influenza A Virus. mBio 9.

Lauterbach, H., Bathke, B., Gilles, S., Traidl-Hoffmann, C., Luber, C.A., Fejer, G., Freudenberg, M.A., Davey, G.M., Vremec, D., Kallies, A., et al. (2010). Mouse CD8alpha+ DCs and human BDCA3+ DCs are major producers of IFN-lambda in response to poly IC. J Exp Med 207, 2703-2717.

Lee, H.C., Chathuranga, K., and Lee, J.S. (2019). Intracellular sensing of viral genomes and viral evasion. Experimental \& molecular medicine 51, 1-13.

Li, W., Xu, H., Xiao, T., Cong, L., Love, M.I., Zhang, F., Irizarry, R.A., Liu, J.S., Brown, M., and Liu, X.S. (2014). MAGeCK enables robust identification of essential genes from genome-scale CRISPR/Cas9 knockout screens. Genome Biol 15, 554.

Li, X., Rydzewski, N., Hider, A., Zhang, X., Yang, J., Wang, W., Gao, Q., Cheng, X., and Xu, H. (2016). A molecular mechanism to regulate lysosome motility for lysosome positioning and tubulation. Nat Cell Biol 18, 404-417.

McFerran, B., and Burgoyne, R. (1997). 2',3'-Cyclic nucleotide 3'-phosphodiesterase is associated with mitochondria in diverse adrenal cell types. J Cell Sci 110 (Pt 23), 2979-2985.

Myrdal, S.E., Johnson, K.C., and Steyger, P.S. (2005). Cytoplasmic and intra-nuclear binding of gentamicin does not require endocytosis. Hear Res 204, 156-169.

O'Connell, R.M., Saha, S.K., Vaidya, S.A., Bruhn, K.W., Miranda, G.A., Zarnegar, B., Perry, A.K., Nguyen, B.O., Lane, T.F., Taniguchi, T., et al. (2004). Type I interferon production enhances susceptibility to Listeria monocytogenes 
infection. J Exp Med 200, 437-445.

Omotade, T.O., and Roy, C.R. (2019). Manipulation of Host Cell Organelles by Intracellular Pathogens. Microbiology spectrum 7. Perkins, D.J., Rajaiah, R., Tennant, S.M., Ramachandran, G., Higginson, E.E., Dyson, T.N., and Vogel, S.N. (2015). Salmonella Typhimurium Co-Opts the Host Type I IFN System To Restrict Macrophage Innate Immune Transcriptional Responses Selectively. Journal of immunology 195, 2461-2471.

903 Prost, L.R., Daley, M.E., Le Sage, V., Bader, M.W., Le Moual, H., Klevit, R.E., and Miller, S.I. (2007). Activation of the 904 bacterial sensor kinase PhoQ by acidic pH. Mol Cell 26, 165-174.

905 Reis, R.C., Sorgine, M.H., and Coelho-Sampaio, T. (1998). A novel methodology for the investigation of intracellular proteolytic processing in intact cells. Eur J Cell Biol 75, 192-197.

907 Ribet, D., and Cossart, P. (2015). How bacterial pathogens colonize their hosts and invade deeper tissues. 908 Microbes and infection 17, 173-183.

909 Robinson, N., McComb, S., Mulligan, R., Dudani, R., Krishnan, L., and Sad, S. (2012). Type I interferon induces necroptosis in macrophages during infection with Salmonella enterica serovar Typhimurium. Nature immunology

911 13, 954-962.

912 Roy, D., Liston, D.R., Idone, V.J., Di, A., Nelson, D.J., Pujol, C., Bliska, J.B., Chakrabarti, S., and Andrews, N.W. (2004).

913 A process for controlling intracellular bacterial infections induced by membrane injury. Science 304, 1515-1518.

914 Schoggins, J.W., MacDuff, D.A., Imanaka, N., Gainey, M.D., Shrestha, B., Eitson, J.L., Mar, K.B., Richardson, R.B.,

915 Ratushny, A.V., Litvak, V., et al. (2014). Pan-viral specificity of IFN-induced genes reveals new roles for cGAS in 916 innate immunity. Nature 505, 691-695.

917 Schoggins, J.W., and Rice, C.M. (2011). Interferon-stimulated genes and their antiviral effector functions. Current 918 opinion in virology 1, 519-525.

919 Song, F., Yi, Y., Li, C., Hu, Y., Wang, J., Smith, D.E., and Jiang, H. (2018). Regulation and biological role of the peptide/histidine transporter SLC15A3 in Toll-like receptor-mediated inflammatory responses in macrophage. Cell death \& disease 9,770 .

922 Spence, J.S., He, R., Hoffmann, H.H., Das, T., Thinon, E., Rice, C.M., Peng, T., Chandran, K., and Hang, H.C. (2019). 923 IFITM3 directly engages and shuttles incoming virus particles to lysosomes. Nature chemical biology 15, 259-268. Steele-Mortimer, O. (2008). The Salmonella-containing vacuole: moving with the times. Curr Opin Microbiol 11, 38-45. IL-10R+ colonic macrophages and dendritic cells and leads to more severe Salmonella colitis. PLoS One 12, e0188600.

929 Thurston, T.L., Wandel, M.P., von Muhlinen, N., Foeglein, A., and Randow, F. (2012). Galectin 8 targets damaged vesicles for autophagy to defend cells against bacterial invasion. Nature 482, 414-418.

931 Tuli, A., and Sharma, M. (2019). How to do business with lysosomes: Salmonella leads the way. Curr Opin 932 Microbiol 47, 1-7.

933 Unsworth, K.E., Way, M., McNiven, M., Machesky, L., and Holden, D.W. (2004). Analysis of the mechanisms of 934 Salmonella-induced actin assembly during invasion of host cells and intracellular replication. Cell Microbiol 6, 935 1041-1055.

936 van der Velden, A.W., Lindgren, S.W., Worley, M.J., and Heffron, F. (2000). Salmonella pathogenicity island 937 1-independent induction of apoptosis in infected macrophages by Salmonella enterica serotype typhimurium. 
938 Infection and immunity 68, 5702-5709.

939 Wee, Y.S., Roundy, K.M., Weis, J.J., and Weis, J.H. (2012). Interferon-inducible transmembrane proteins of the

940 innate immune response act as membrane organizers by influencing clathrin and v-ATPase localization and

941 function. Innate Immun 18, 834-845.

942 Welch, M.D. (2015). Why should cell biologists study microbial pathogens? Molecular biology of the cell 26,

943 4295-4301.

944 Wilson, R.P., Tursi, S.A., Rapsinski, G.J., Medeiros, N.J., Le, L.S., Kotredes, K.P., Patel, S., Liverani, E., Sun, S., Zhu, W.,

945 et al. (2019). STAT2 dependent Type I Interferon response promotes dysbiosis and luminal expansion of the

946 enteric pathogen Salmonella Typhimurium. PLoS Pathog 15, e1007745.

947 Xu, Y., Zhou, P., Cheng, S., Lu, Q., Nowak, K., Hopp, A.K., Li, L., Shi, X., Zhou, Z., Gao, W., et al. (2019). A Bacterial

948 Effector Reveals the V-ATPase-ATG16L1 Axis that Initiates Xenophagy. Cell 178, 552-566 e520.

949 Yeung, A.T.Y., Choi, Y.H., Lee, A.H.Y., Hale, C., Ponstingl, H., Pickard, D., Goulding, D., Thomas, M., Gill, E., Kim, J.K., 950 et al. (2019). A Genome-Wide Knockout Screen in Human Macrophages Identified Host Factors Modulating 951 Salmonella Infection. mBio 10.

952 Yoshimori, T., Yamamoto, A., Moriyama, Y., Futai, M., and Tashiro, Y. (1991). Bafilomycin A1, a specific inhibitor of 953 vacuolar-type $\mathrm{H}(+)$-ATPase, inhibits acidification and protein degradation in lysosomes of cultured cells. J Biol 954 Chem 266, 17707-17712. 
bioRxiv preprint doi: https://doi.org/10.1101/2020.02.25.965061; this version posted April 30, 2020. The copyright holder for this preprint (which was not certified by peer review) is the author/funder, who has granted bioRxiv a license to display the preprint in perpetuity. It is made available under aCC-BY-NC-ND 4.0 International license.

A

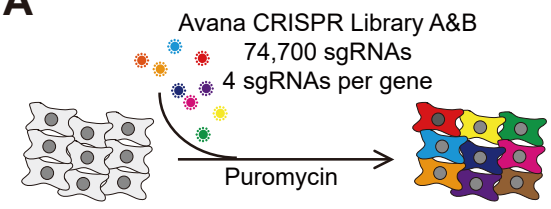

S. typhimurium (Stm) infection

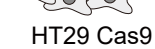

Human intestinal epithelial cells
Genome-wide KO library A\&B

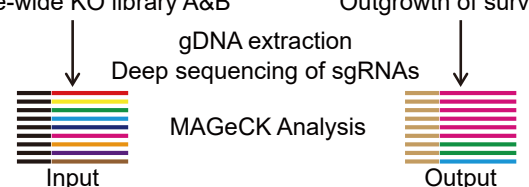

B

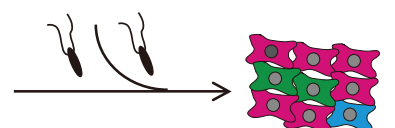

Outgrowth of survivors

Regulation of actin filament organization Fc $\gamma$ receptor pathway involved in phagocytosis

Type I interferon signaling pathway Attachment of GPI anchor to protein Glycolipid biosynthetic process Response to interleukin- 6 Ephrin receptor signaling pathway

Rac protein signal transduction Phagocytosis

Arp2/3 complex-mediated actin nucleation

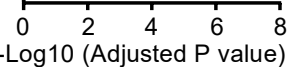

D

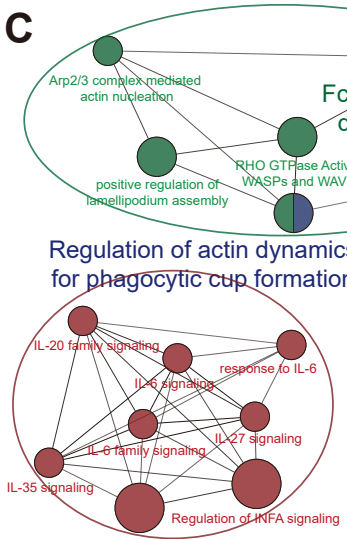

Type I interferon signaling pathway
Fcgamma receptor (FCGR) dependent phagocytosis

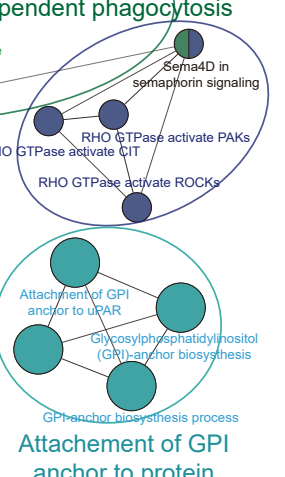

anchor to protein

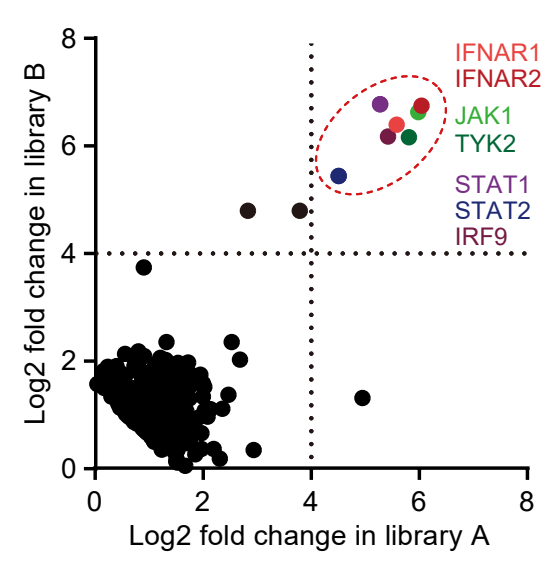

E

Ranks of Hits in Library (A, B)

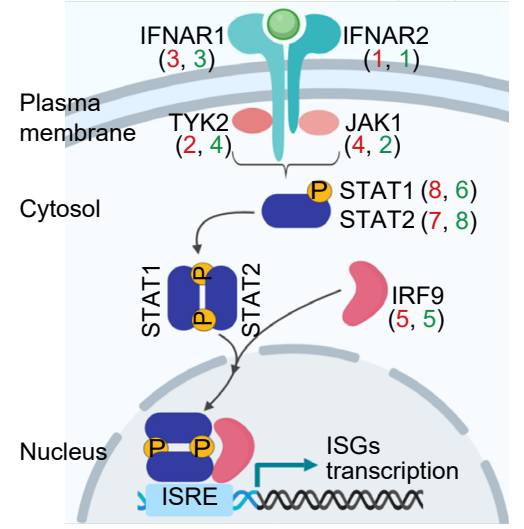


bioRxiv preprint doi: https://doi.org/10.1101/2020.02.25.965061; this version posted April 30, 2020. The copyright holder for this preprint (which was not certified by peer review) is the author/funder, who has granted bioRxiv a license to display the preprint in perpetuity. It is made available under aCC-BY-NC-ND 4.0 International license.

A

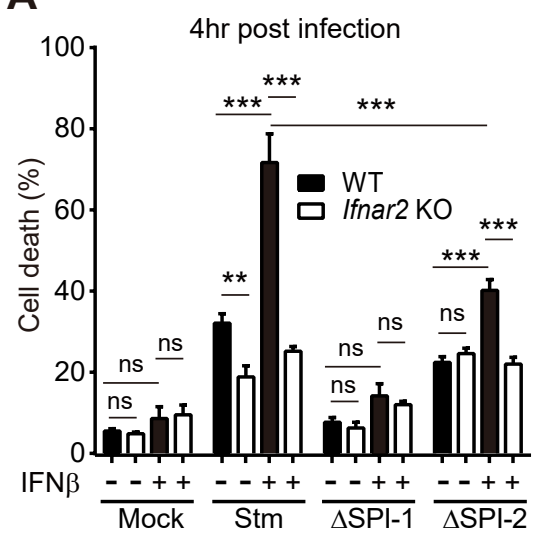

B

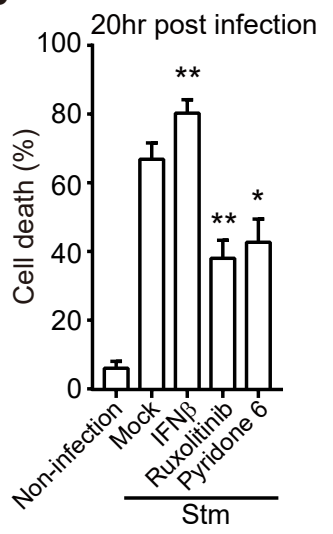

C
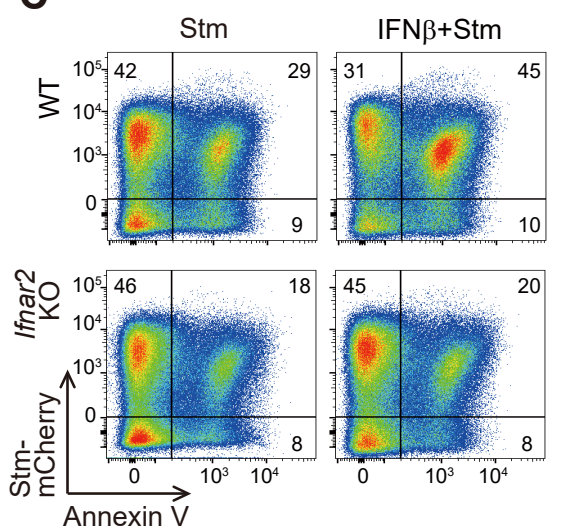

F

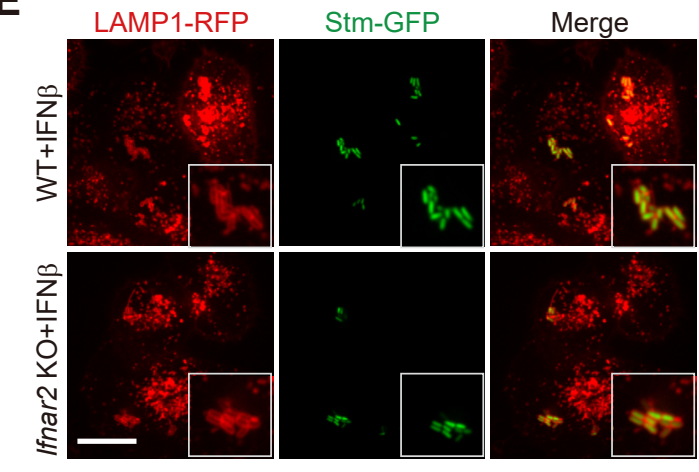

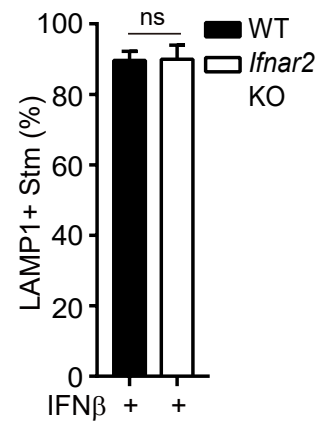


bioRxiv preprint doi: https://doi.org/10.1101/2020.02.25.965061; this version posted April 30, 2020. The copyright holder for this preprint (which was not certified by peer review) is the author/funder, who has granted bioRxiv a license to display the preprint in perpetuity. It is made available under aCC-BY-NC-ND 4.0 International license.

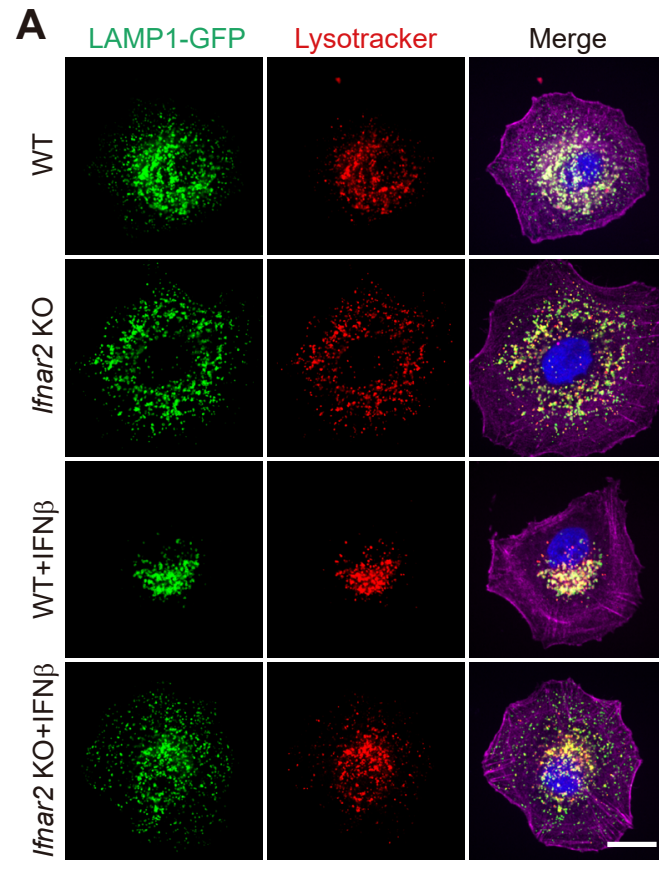

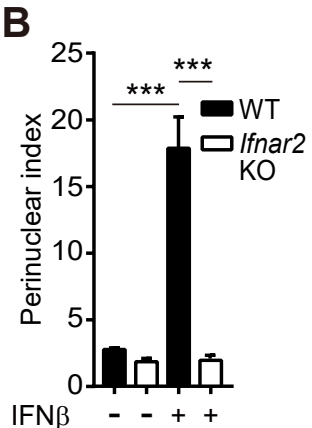

IFN $\beta-\cdot+$

D

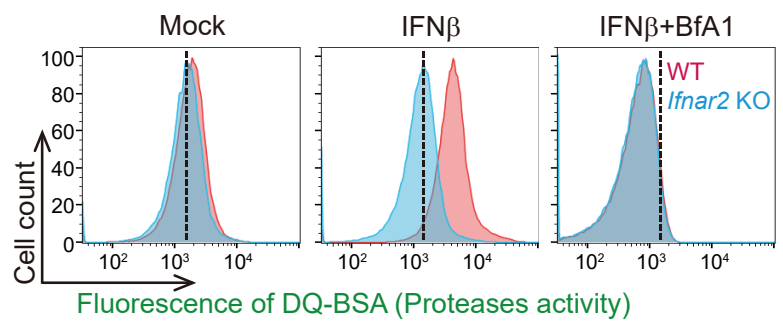

C

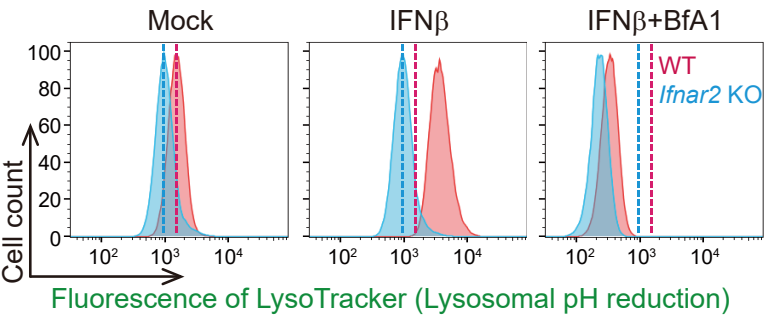

$\mathbf{E}$

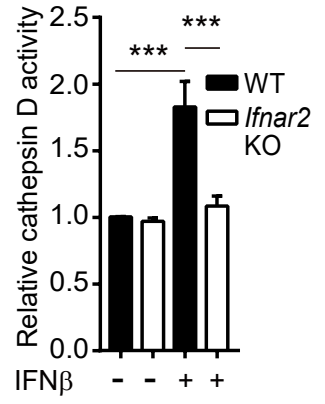

Figure. 3 
bioRxiv preprint doi: https://doi.org/10.1101/2020.02.25.965061; this version posted April 30, 2020. The copyright holder for this preprint (which was not certified by peer review) is the author/funder, who has granted bioRxiv a license to display the preprint in perpetuity. It is made available under aCC-BY-NC-ND 4.0 International license.

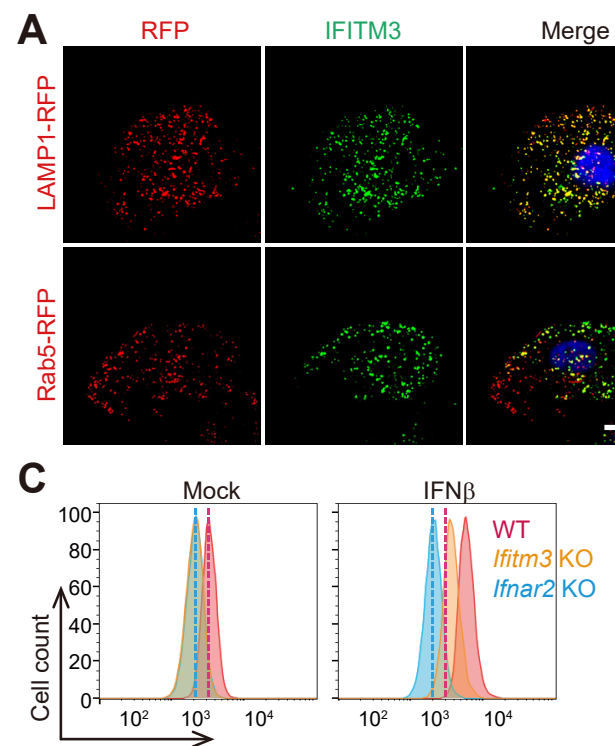

Fluorescence of LysoTracker (Lysosomal pH reduction)

D

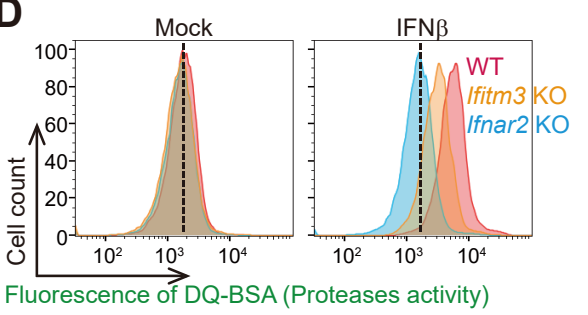

E
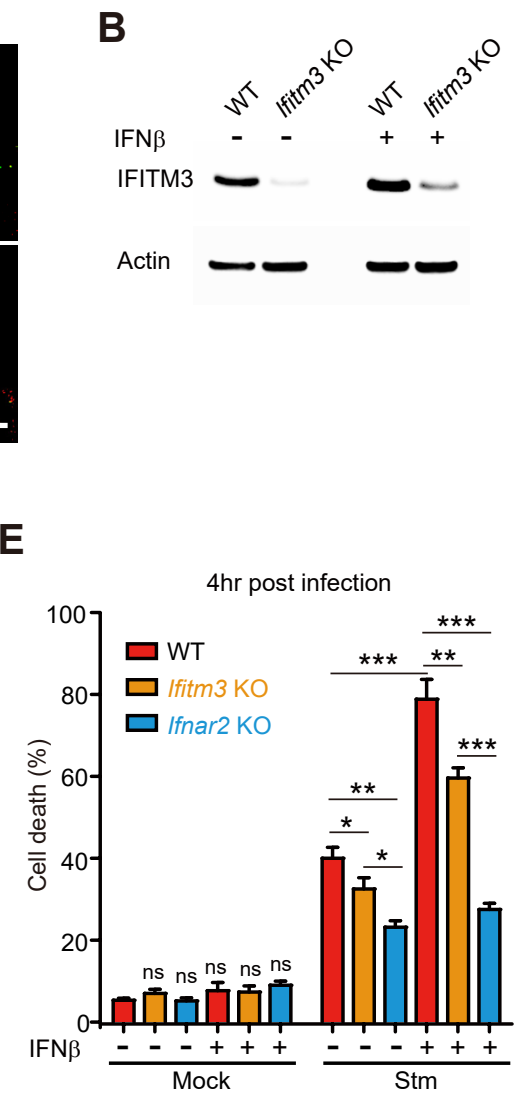

Figure. 4 
bioRxiv preprint doi: https://doi.org/10.1101/2020.02.25.965061; this version posted April 30, 2020. The copyright holder for this preprint (which was not certified by peer review) is the author/funder, who has granted bioRxiv a license to display the preprint in perpetuity. It is made available under aCC-BY-NC-ND 4.0 International license.

A

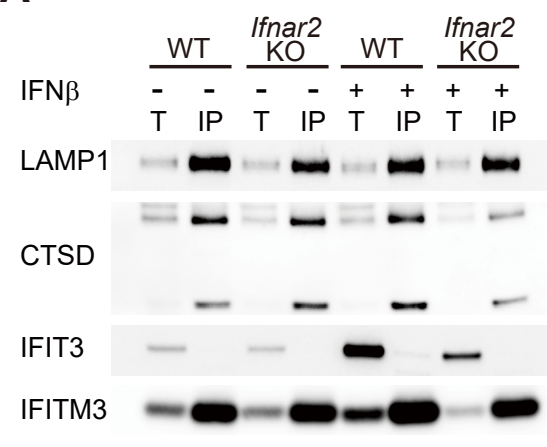

B

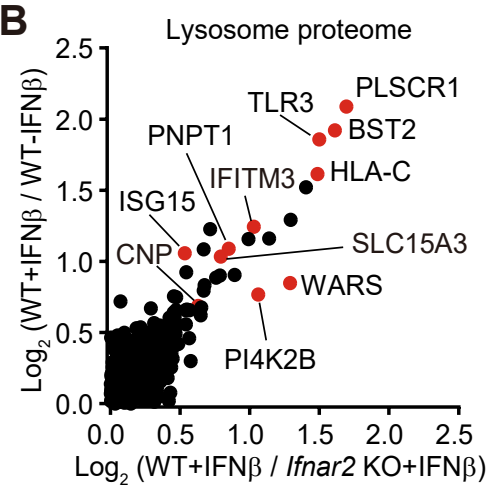

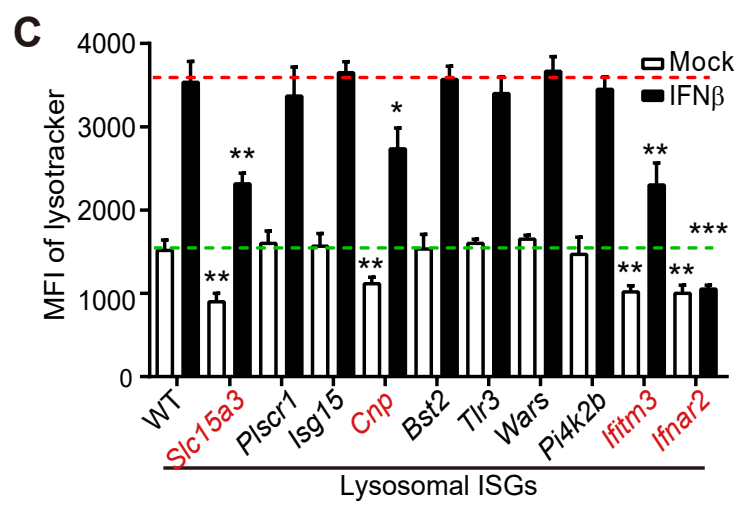

Figure. 5 
bioRxiv preprint doi: https://doi.org/10.1101/2020.02.25.965061; this version posted April 30, 2020. The copyright holder for this preprint (which was not certified by peer review) is the author/funder, who has granted bioRxiv a license to display the preprint in perpetuity. It is made available under aCC-BY-NC-ND 4.0 International license.

A

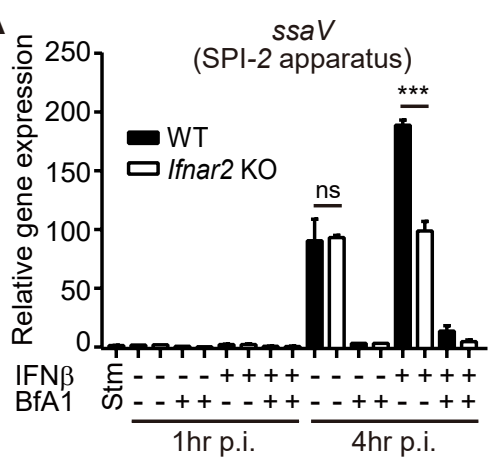

D

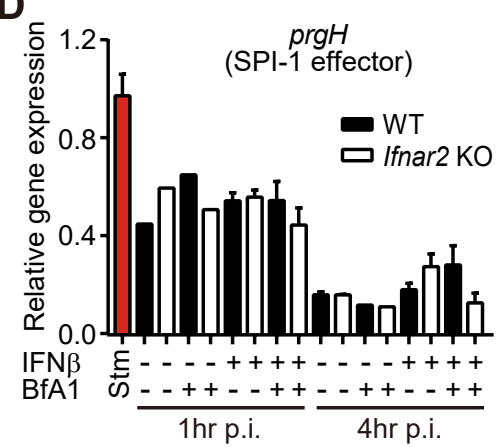

B

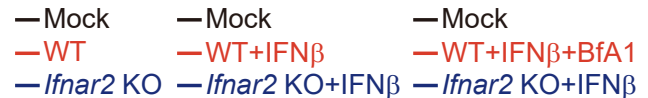

- Ifnar2 KO - Ifnar2 KO+IFN $\beta$ - Ifnar2 KO+IFN $\beta$

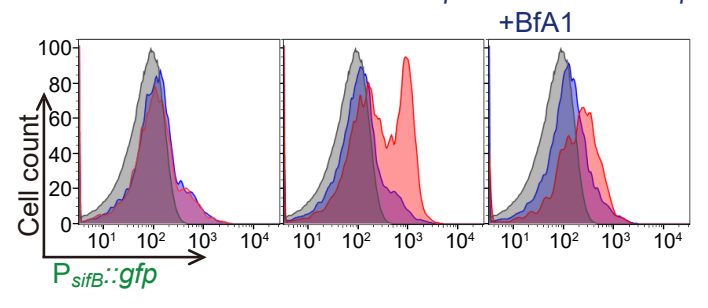

E

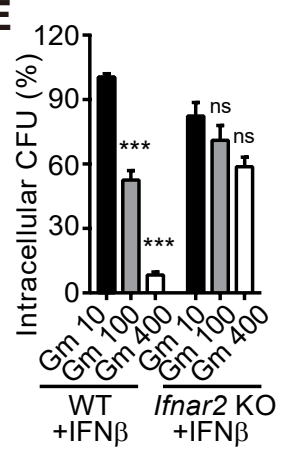

F

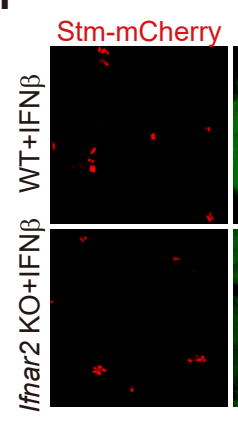

C

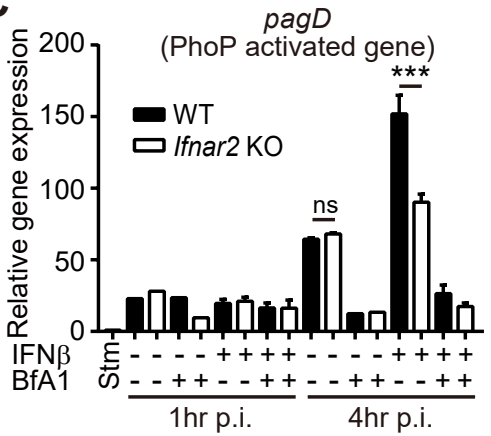

Gal3-GFP

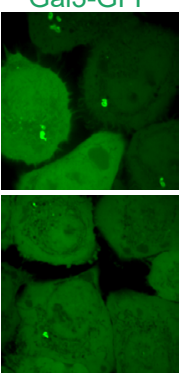

Merge

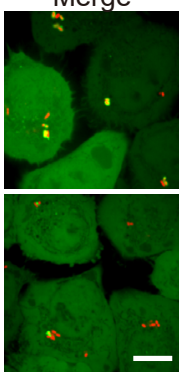

G

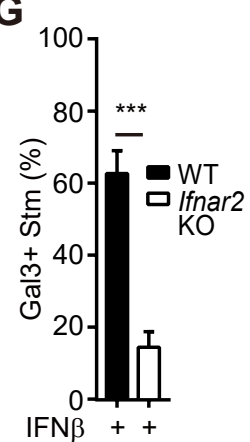


bioRxiv preprint doi: https://doi.org/10.1101/2020.02.25.965061; this version posted April 30, 2020. The copyright holder for this preprint (which was not certified by peer review) is the author/funder, who has granted bioRxiv a license to display the preprint in perpetuity. It is made available under aCC-BY-NC-ND 4.0 International license.

A
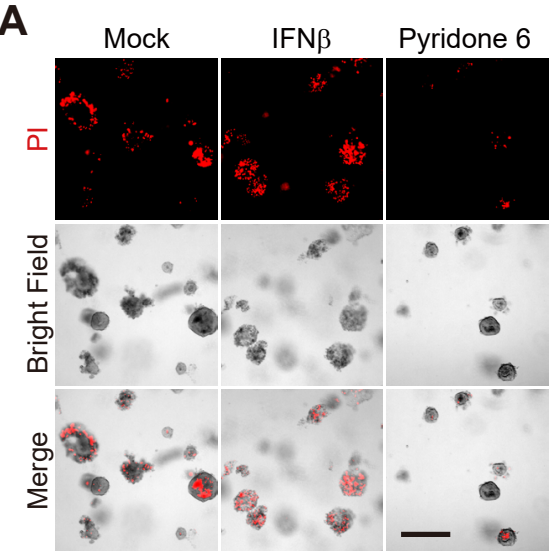

D

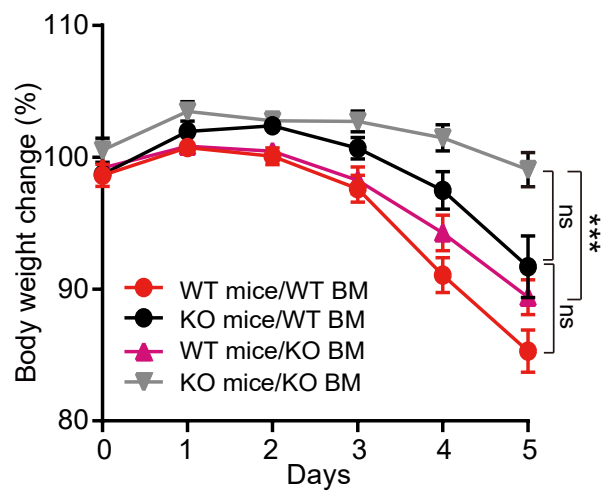

$\mathbf{F}$

F WT mice/WT BM

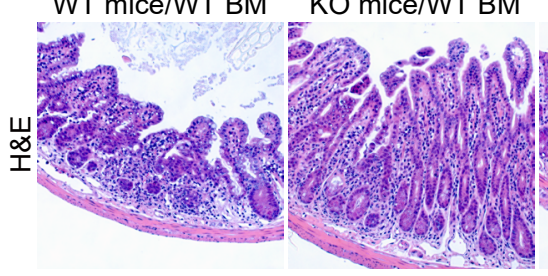

H

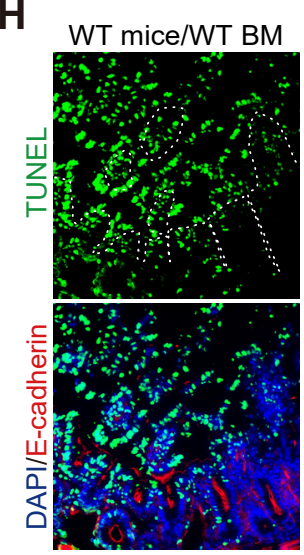

B

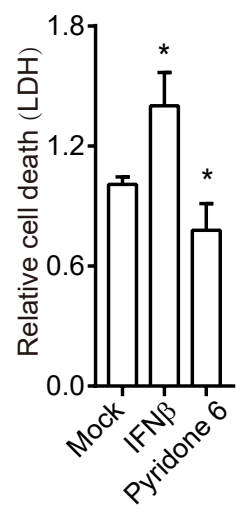

E

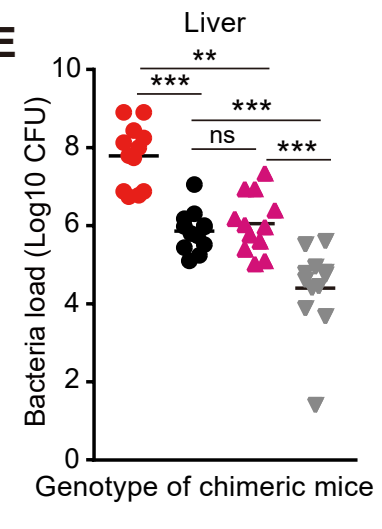

C

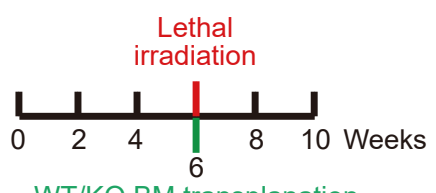

WT/KO BM transplanation to WT/KO mice
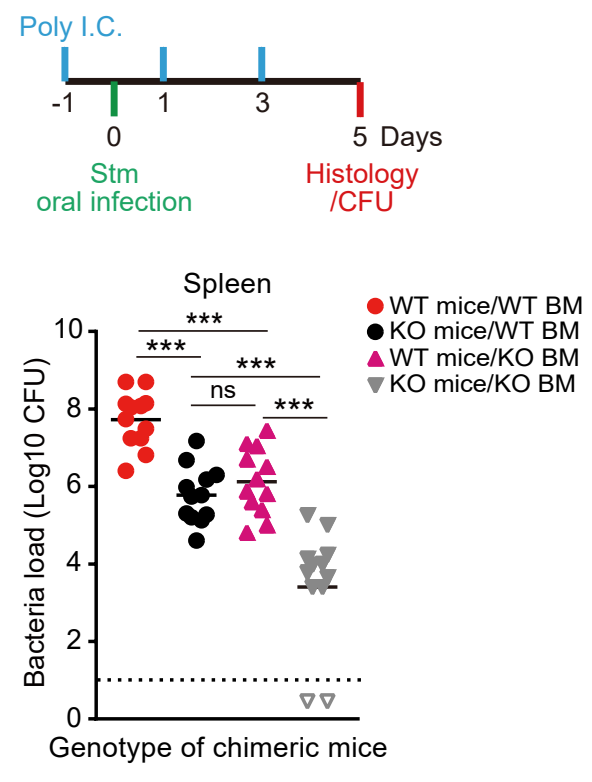